\title{
Range Vegetation and Sheep Production at Three Stocking Rates on Stipa-Bouteloua Prairie
}

\section{S. SMOLIAK}

Highlight: Stipa-Bouteloua prairie was grazed by sheep at three stocking rates over a 19-year period. Under continuous heavy grazing the vegetative cover and forage yield deteriorated mainly through the large increase in blue grama and the decrease in the more productive grasses. The mature ewes grazed at the heavy rate were lighter in body weight and gave birth to smaller lambs, which were weaned at lower body weights, than those grazed at the moderate or light intensities of use. The Stipa-Bouteloua prairie should be stocked at not less than 1.0 acre per ewe per month to maintain the vegetative cover in a productive condition.

Controlled grazing trials with sheep in the northern Great Plains area have been limited in number. In Montana, Woolfolk (1949) studied three rates of grazing and found that a minimum of 0.67 surface acre of range per month was required for normal development and maintenance of a dry yearling ewe. At this rate of stocking there was some improvement in the range vegetation and a desirable carryover of unused forage at the end of each grazing season. On heavily stocked range, yearling ewes gained significantly less weight than those on conservatively or lightly stocked range. After 6 years of heavy stocking, the composition of the range vegetation shifted from a predominance of perennials to a cover of lowvalue annual species. In Wyoming, Lang et al. (1956) used ewes and lambs to evaluate three rates of grazing on shortgrass prairie over a 10 -year period. Both ewes and lambs gained more per animal on the lightly grazed pastures than on those heavily utilized. Blue grama (Bouteloua gracilis (H.B.K.) Lag.) and buffalo grass (Buchloe dactyloides (Nutt.) Engelm.) increased in percentage of total basal cover with increasingly close grazing. Needleandthread (Stipa comata Trin. and Rupr.) and western wheatgrass (Agropyron smithii Rydb.) decreased with increased grazing pressure. After 9 years, forage production on the heavily grazed pastures was considerably less than on those lightly or moderately used. In a second 10-year trial (Rauzi and Lang, 1967), significantly more midgrasses were produced on lightly grazed pastures than on moderately grazed pastures, but no

The author is research scientist, Research Station, Canada Department of Agriculture, Leth bridge, Alberta.

Manuscript received April 27, 1973. differences in lamb or ewe body weight gains were found.

Results of stocking rate studies on Stipa-Bouteloua prairie grazed by cattle have been reported (Clarke et al., 1943; Peters, 1955). However, changes in composition of vegetation resulting from grazing by cattle and reaction of species to brought about by sheep grazing (Thetford et al., 1971).

The present study was initiated in 1951 to determinc the effect of sheep grazing at three stocking rates on the floristic composition and forage production of Stipa-Bouteloua prairie and on lamb and ewe production.

\section{Study Area and Methods}

The vegetation of the area has been described by Clarke et al. $(1942,1943)$ and Smoliak (1965). The grazing trial was conducted at the Agriculture Canada Research Substation, Manyberries, Alberta, from 1951 to 1969 .

Native range was grazed at rates of $0.83,1.0$, and 1.25 acres per ewe per month during a 9-month grazing period. The experimental area consisted of three summer fields, 100, 120, and 150 acres, respectively, grazed by white-faced, mature ewes and their lambs for 6 months, May 1 to October 31 , and three fall-spring pastures, each half the size of the original three, grazed by ewes at the same rates for 3 months, November 1 to December 31 and from April 1 to 30 . (Fig. 1) During the three remaining winter months, January 1 to March 31 , the ewes were pen fed 3.3, 4.0, and $5.0 \mathrm{lb}$ alfalfa hay per head per day in groups corresponding to the grazing rates.

During the period 1951 to 1963,20 ewes with lambs, and from 1964 to 1969 , 18 ewes with their lambs, and 3 yearling ewes were grazed in each of the fields. Each year, an equal number of ewes from cattle grazing are different from those each age group, ranging from 2 to 7 years old, were maintained on each treatment. The ewes remained on the experiment until they were 7 years old or were barren for 1 year. Temporary replacements for ewes that died during the trial were made with ewes of similar age from the main flock. Permanent replacements were made in each treatment each April 1, with an equal number of 2-year-old ewes retained as lambs from within each treatment.

The ewes bred and lambed while in the winter fields. Two rams were used each year, and half the ewes in each treatment were pen bred at night to each ram. The breeding season lasted from November 15 to December 31 each year from 1952 to 1963 , and from November 1 to December 15 each year from 1964 to 1969 . Lambs were weaned on October 1, except during the period 1952-1963, when ram lambs were weaned the third week of August.

Initial, 28-day, and final weights were recorded for the ewes and lambs on the summer and winter treatments. The sheep were penned overnight without feed and water (15 hours) and then weighed. Birth weights of lambs and weights and condition scores of ewes were obtained within 24 hours of lambing. Weaning weights of lambs were adjusted for sex and type of birth and rearing by employing the constants developed by MacNaughton (1956).

Effects of grazing on the plant cover were determined by the point quadrat method (Clarke et al., 1942). A total of 4,200 points were taken on each pasture in the summer in each year of the study. Forage production and utilization was estimated by the difference method from yields obtained from 10 caged and uncaged square-yard plots in each pasture at the end of the grazing season.

\section{Results}

\section{Vegetation}

Vegetational analysis of the three summer fields showed that differences in percentage basal area occurred after 19 years of grazing by sheep (Table 1). Blue grama increased in basal area on the heavily grazed field, whereas needleandthread increased on the moderately and lightly grazed fields. Junegrass (Koeleria cristata (L.) Pers.) and Sandberg blue- 


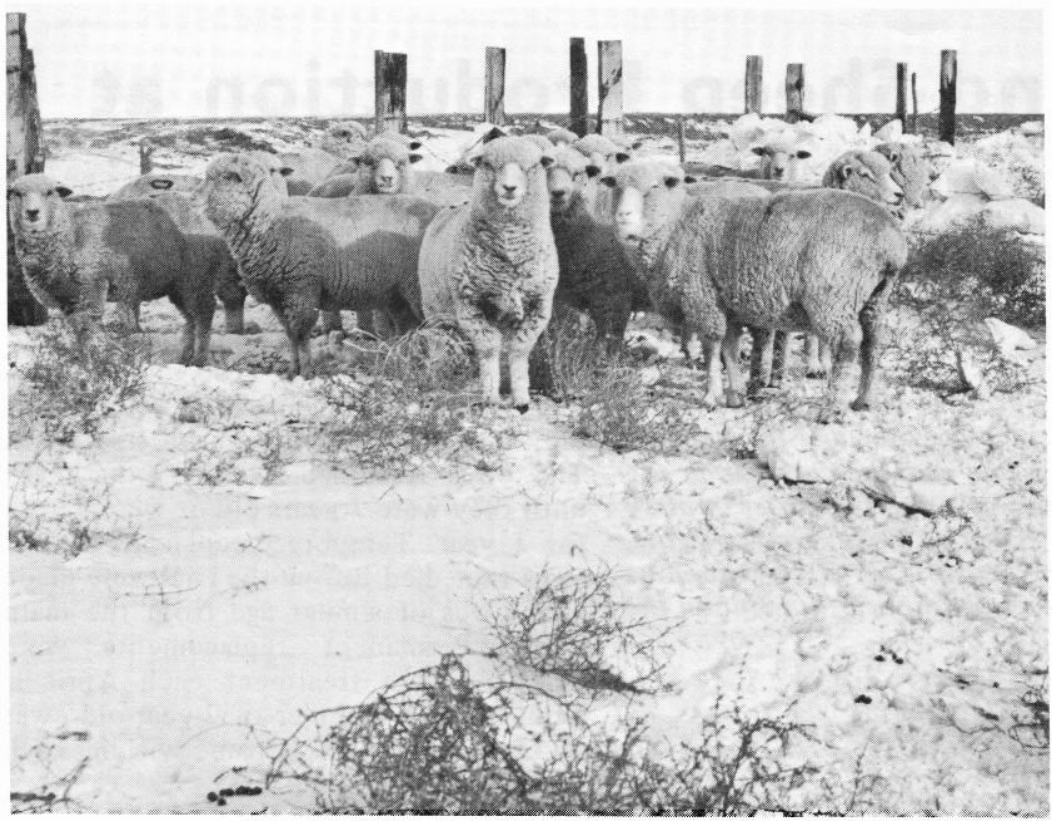

Fig. 1. Ewes on fall pastures usually encountered difficult grazing conditions. However, during January 1 to March 31 they were fed hay in pens.

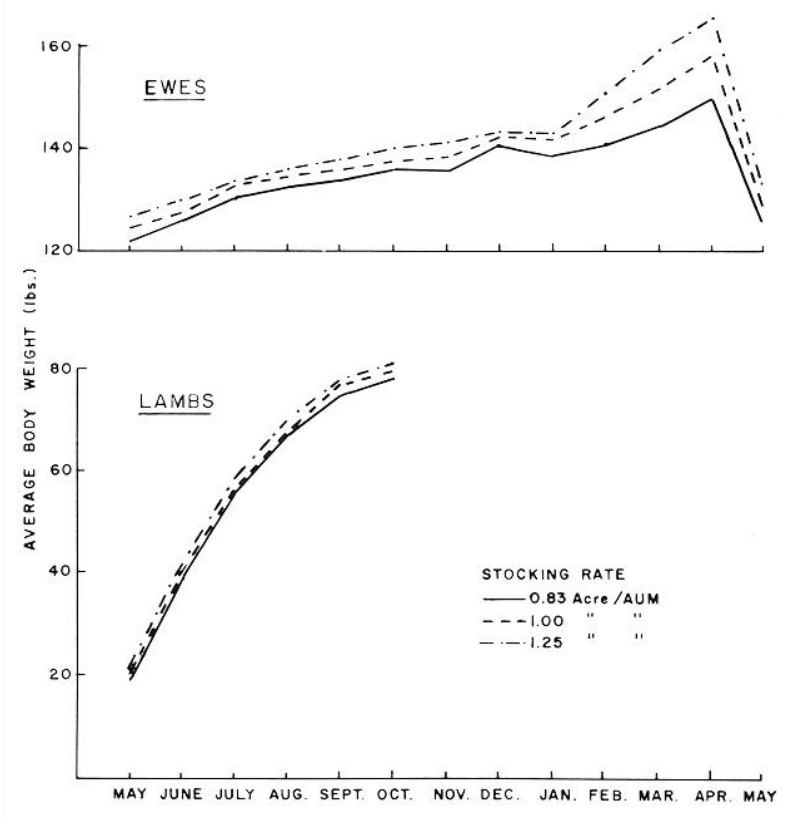

Fig. 2. Average 28-day weights of ewes and lambs grazed at three stocking rates, 1951-1969. grass (Poa secunda Presl.) increased in basal area on all fields. Western wheatgrass decreased in basal area on the heavily and moderately grazed fields, but the greatest decrease was on the heavily grazed field. Sedges decreased in area on the lightly grazed field. The total grass and sedge cover increased on all fields but the changes were not significant.

Taller growing grasses, needleandthread, western wheatgrass, and "other grasses" decreased in percentage composition (Table 1) under 19 years of heavy grazing. In 1951 taller grasses contributed
$37.6 \%$ toward total composition, excluding little clubmoss (Selaginella densa Rydb.), but in 1969 the contribution was only $16.4 \%$. Short growing grasses, blue grama, Junegrass, and Sandberg's bluegrass contributed $38.1 \%$ of the total composition in 1951 and $63.6 \%$ in 1969 . Composition values for fields grazed moderately and lightly show that grass cover improved slightly during the study period. The percentage composition of blue grama decreased and that of needleand thread increased during this period.

Percentage basal area of fringed sage (Artemisia frigida Willd.) decreased on all fields, and that of moss phlox (Phlox hoodii Richards) and pricklypear (Opuntia polyacantha Haw.) decreased on the heavily and moderately grazed fields. Woolly plantain (Plantago purshii R. and $\mathrm{S}$.) increased in basal area on fields grazed heavily and moderately. There was a general decrease in basal area and composition of total forbs on all fields. Little clubmoss increased in basal area on all fields.

Forage production over the 19-year period reflected the effects of seasonal (April to July, inclusive) precipitation and grazing (Table 2). During the first 6

Table 1. Basal area (\%) and composition (\%) of vegetation on fields grazed at three intensities, Manyberries, Alberta, $1951-1969$.

\begin{tabular}{|c|c|c|c|c|c|c|c|c|c|c|c|c|}
\hline \multirow[b]{3}{*}{ Species } & \multicolumn{4}{|c|}{ Heavy } & \multicolumn{4}{|c|}{ Moderate } & \multicolumn{4}{|c|}{ Light } \\
\hline & \multicolumn{2}{|c|}{ Basal area } & \multicolumn{2}{|c|}{ Composition } & \multicolumn{2}{|c|}{ Basal area } & \multicolumn{2}{|c|}{ Composition } & \multicolumn{2}{|c|}{ Basal area } & \multicolumn{2}{|c|}{ Composition } \\
\hline & 1951 & 1969 & 1951 & 1969 & 1951 & 1969 & 1951 & 1969 & 1951 & 1969 & 1951 & 1969 \\
\hline Blue grama & 2.2 & $3.6 * *$ & 32.7 & 48.3 & 2.9 & 2.8 & 36.3 & 33.6 & 2.8 & 2.4 & 37.4 & 29.2 \\
\hline Needleand thread & 0.5 & 0.5 & 7.5 & 6.5 & 0.7 & 1.2 & 8.8 & 14.3 & 0.4 & $1.3^{* *}$ & 5.0 & 16.1 \\
\hline Junegrass & 0.1 & $0.4 * *$ & 1.8 & 6.0 & 0.3 & $0.6 * *$ & 3.2 & 6.9 & 0.2 & $0.6 * *$ & 2.8 & 7.9 \\
\hline Western wheatgrass & 1.9 & $0.7 * *$ & 28.0 & 9.9 & 1.6 & 1.2 & 20.5 & 14.3 & 1.7 & 1.7 & 22.6 & 20.5 \\
\hline Sandberg bluegrass & 0.2 & $0.7 * *$ & 3.6 & 9.3 & 0.5 & $0.9 * *$ & 5.9 & 10.7 & 0.4 & $0.9 * *$ & 6.0 & 11.4 \\
\hline Other grasses & 0.1 & 0.0 & 2.1 & 0.0 & 0.2 & 0.0 & 2.0 & 0.0 & 0.0 & 0.0 & 0.0 & 0.0 \\
\hline Sedges & 1.1 & 1.1 & 15.8 & 14.4 & 0.9 & 0.8 & 10.5 & 9.5 & 1.1 & $0.5 * *$ & 14.6 & 6.1 \\
\hline Total grasses and sedges & 6.1 & 7.0 & 91.5 & 94.4 & 7.1 & 7.5 & 87.2 & 89.3 & 6.6 & 7.4 & 88.4 & 91.2 \\
\hline Fringed sage & 0.1 & trace & 0.8 & 0.3 & 0.2 & 0.1 & 2.1 & 1.2 & 0.2 & trace & 2.5 & 0.3 \\
\hline Moss phlox & 0.2 & $0.1 *$ & 2.9 & 1.6 & 0.4 & 0.3 & 5.0 & 4.0 & 0.1 & 0.1 & 1.3 & 1.7 \\
\hline Woolly plantain & 0.1 & $0.2 * *$ & 2.1 & 3.2 & 0.3 & $0.4 *$ & 3.5 & 4.6 & 0.4 & 0.3 & 5.0 & 4.0 \\
\hline Prickly pear & 0.1 & trace & 1.8 & 0.5 & 0.1 & trace & 1.7 & 0.6 & 0.1 & 0.1 & 1.9 & 1.2 \\
\hline Other forbs & 0.1 & 0.0 & 0.9 & 0.0 & trace & trace & 0.5 & 0.3 & 0.1 & 0.1 & 0.9 & 1.6 \\
\hline Total forbs & 0.6 & 0.3 & 8.5 & 5.6 & 1.0 & 0.8 & 12.8 & 10.7 & 0.9 & 0.6 & 11.6 & 8.8 \\
\hline Totals & 6.7 & 7.3 & 100.0 & 100.0 & 8.1 & 8.3 & 100.0 & 100.0 & 7.5 & 8.0 & 100.0 & 100.0 \\
\hline Little clubmoss & 10.7 & $26.0^{* *}$ & & & 9.7 & $22.6 * *$ & & & 9.8 & $18.7 * *$ & & \\
\hline
\end{tabular}

* Significantly different from 1951 values at $P<0.05$.

**Significantly different from 1951 values at $P<0.01$. 
Table 2. Precipitation (inches), forage production (lb/acre oven-dry) and forage utilization (\%) during grazing experiment, 1951-1969, Manyberries, Alberta.

\begin{tabular}{|c|c|c|c|c|c|c|c|}
\hline \multirow[b]{3}{*}{ Year } & \multirow{3}{*}{$\begin{array}{l}\text { Precipita- } \\
\text { tion April } \\
\text { to July incl. }\end{array}$} & \multicolumn{6}{|c|}{ Rate of grazing } \\
\hline & & \multicolumn{2}{|c|}{ Heavy } & \multicolumn{2}{|c|}{ Moderate } & \multicolumn{2}{|c|}{ Light } \\
\hline & & $\begin{array}{l}\text { Forage } \\
\text { produced }\end{array}$ & $\begin{array}{l}\% \text { util- } \\
\text { ization }\end{array}$ & $\begin{array}{l}\text { Forage } \\
\text { produced }\end{array}$ & $\begin{array}{l}\% \text { util- } \\
\text { ization }\end{array}$ & $\begin{array}{l}\text { Forage } \\
\text { produced }\end{array}$ & $\begin{array}{l}\text { \% util- } \\
\text { ization }\end{array}$ \\
\hline 1951 & 6.10 & 395 & 43 & 440 & 37 & 455 & 21 \\
\hline 1952 & 5.21 & 415 & 57 & 435 & 52 & 480 & 39 \\
\hline 1953 & 8.40 & 510 & 43 & 530 & 39 & 620 & 32 \\
\hline 1954 & 7.94 & 415 & 60 & 450 & 53 & 530 & 44 \\
\hline 1955 & 13.28 & 410 & 48 & 445 & 46 & 620 & 37 \\
\hline 1956 & 8.19 & 650 & 50 & 690 & 44 & 700 & 39 \\
\hline 1957 & 4.40 & 360 & 56 & 435 & 47 & 475 & 44 \\
\hline 1958 & 5.05 & 315 & 72 & 365 & 50 & 395 & 34 \\
\hline 1959 & 5.82 & 255 & 68 & 335 & 46 & 345 & 40 \\
\hline 1960 & 5.38 & 330 & 84 & 420 & 68 & 455 & 63 \\
\hline 1961 & 3.07 & 145 & 96 & 250 & 75 & 330 & 68 \\
\hline 1962 & 6.58 & 140 & 86 & 265 & 55 & 300 & 52 \\
\hline 1963 & 5.76 & 130 & 79 & 260 & 54 & 310 & 47 \\
\hline 1964 & 6.26 & 110 & 85 & 185 & 54 & 230 & 50 \\
\hline 1965 & 16.48 & 315 & 65 & 340 & 54 & 360 & 45 \\
\hline 1966 & 6.10 & 335 & 64 & 385 & 45 & 430 & 36 \\
\hline 1967 & 6.90 & 265 & 60 & 340 & 50 & 390 & 45 \\
\hline 1968 & 4.95 & 290 & 78 & 385 & 69 & 420 & 66 \\
\hline 1969 & 3.80 & 95 & 95 & 125 & 71 & 195 & 62 \\
\hline \multicolumn{8}{|l|}{ Average } \\
\hline $1951-1969$ & 6.82 & $309 a$ & $68 \mathrm{a}$ & $373 \mathrm{ab}$ & $53 b$ & $423 \mathrm{~b}$ & $45 \mathrm{~b}$ \\
\hline \multicolumn{8}{|l|}{ Average } \\
\hline $1928-1969$ & 6.29 & & & & & & \\
\hline
\end{tabular}

$a-b$ Means followed by the same letters are not significantly different at the $5 \%$ level. (Duncan's multiple range test.) years of the trial (1951 to 1956 , inclusive), when the average seasonal precipitation exceeded the long-term average, forage production in the three fields was similar. From 1957 to 1969 differences in forage production became more evident on fields grazed at the three intensities. Average production of forage on the heavily grazed field was significantly less than on the lightly grazed field. Average production of forage on

the moderately grazed field did not differ from that on the heavily or lightly grazed fields.

Consumption of forage generally was greater at the heavy rate of use than at the moderate or light rates (Table 2). The percentage consumption of forage was low during the years of favorable growth, 1951 to 1959 . However, during the last 10-year period, 1960 to 1969 , forage consumption averaged $78 \%$ at the heavy

Table 3. Sheep production at three rates of grazing, Manyberries, Alberta, 1951-1969.

\begin{tabular}{cccc}
\hline & \multicolumn{3}{c}{ Rate of grazing } \\
\cline { 3 - 4 } Characteristic & Heavy & Moderate & Light \\
\hline Ewes & & & \\
& & & \\
Summer gains (lb) & $12.3 \mathrm{a}$ & $12.3 \mathrm{a}$ & $12.6 \mathrm{a}$ \\
Winter gains (lb) & $-10.1 \mathrm{a}$ & $-9.4 \mathrm{ab}$ & $-7.7 \mathrm{~b}$ \\
Average annual gain (lb) & $2.2 \mathrm{a}$ & $2.9 \mathrm{ab}$ & $4.9 \mathrm{~b}$ \\
Number ewes died & 8 & 13 & 15 \\
Lambs & & & \\
Number born & $542 \mathrm{a}$ & $542 \mathrm{a}$ & $534 \mathrm{a}$ \\
Number weaned & $446 \mathrm{a}$ & $442 \mathrm{a}$ & $450 \mathrm{a}$ \\
Birth weight (lb) & $9.5 \mathrm{a}$ & $9.7 \mathrm{ab}$ & $10.0 \mathrm{~b}$ \\
Corrected weaning weight (lb) & $78.6 \mathrm{a}$ & $81.6 \mathrm{~b}$ & $81.6 \mathrm{~b}$ \\
Summer gain (lb) & $57.2 \mathrm{a}$ & $58.1 \mathrm{a}$ & $58.0 \mathrm{a}$ \\
Lamb weaned (lb/year) & $1793 \quad \mathrm{a}$ & $1830 \mathrm{a}$ & $1855 \mathrm{a}$ \\
Ewe lambing record & & & \\
\% rated Good condition & $52.5 \mathrm{a}$ & $67.7 \mathrm{~b}$ & $72.5 \mathrm{~b}$ \\
\% rated Fair condition & $24.7 \mathrm{a}$ & $21.1 \mathrm{ab}$ & $15.5 \mathrm{~b}$ \\
\% rated Poor condition & $17.0 \mathrm{a}$ & $8.5 \mathrm{~b}$ & $6.5 \mathrm{~b}$ \\
\% died, dry, or aborted & $5.8 \mathrm{a}$ & $4.7 \mathrm{a}$ & $6.5 \mathrm{a}$ \\
\hline
\end{tabular}

a-c Means followed by the same letters are not significantly different at the $5 \%$ level. (Duncan's multiple range test.) rate, $60 \%$ at the modcrate rate, and $54 \%$ at the light rate of use.

\section{Animal Production}

There were significant differences in body weight gains during the winter period and in average annual weight gains of ewes grazing at the different intensities (Table 3). Summer body weight gains of ewes were similar under the three rates of grazing over the 19-year period. Mortality of ewes increased as grazing intensity decreased, but these differences were not significant.

There were no differences in total number of lambs born or weaned at the three rates of grazing. However, birth weights and corrected weaning weights differed significantly. Lambs born and weaned on the heavy rate of grazing regime were lighter than those on the light rate of grazing. Lambs on the moderately grazed field had a greater corrected weaning weight than lambs on the heavily grazed field. There were no differences in summer gains of lamb or in total pounds of lamb weaned per year at the various rates of grazing.

During lambing, a greater proportion of ewes that graded "good" in condition had been grazed at the moderate or light rate of use. A greater proportion of ewes graded "fair" or "poor" had been grazed at the heavy rate. There were no differences in percentage of ewes that were dry or that died or aborted at the various rates of grazing.

Average 28-day weights of ewes and lambs are shown in Figure 2. Ewes that grazed at the light intensity of use consistently weighed more than those that grazed at the heavy rate throughout the year. Ewes that grazed at the moderate rate were intermediate in body weight. The ewes were heaviest and body weight differences among stocking rates were greatest during April, before lambing. During the summer period lambs on the lightly grazed fields were consistently heavier than those on the heavily grazed fields, but the differences were not significant.

Total gains per acre of ewe and lamb in summer were $16.2,13.6$, and $11.0 \mathrm{lb}$ on the heavy, moderate, and light rates of grazing over the 19-year period. These differences were similar in each of the study years and were significant. The gains per acre on the heavily grazed field ranged from $9.1 \mathrm{lb}$ (1955) to $22.8 \mathrm{lb}$ (1962) and the gains on the lightly grazed field ranged from $6.4 \mathrm{lb}$ (1955) to 14.9 (1962 and 1965). 
Table 4. Lambing weights (lb) of ewes at three rates of grazing, Manyberries, Alberta, 1951-1969.

\begin{tabular}{|c|c|c|c|c|c|c|}
\hline \multirow[b]{3}{*}{ Year } & \multicolumn{6}{|c|}{ Rate of grazing } \\
\hline & \multicolumn{2}{|c|}{ Heavy } & \multicolumn{2}{|c|}{ Moderate } & \multicolumn{2}{|c|}{ Light } \\
\hline & $\begin{array}{c}\text { No. of } \\
\text { ewes }\end{array}$ & Weight & $\begin{array}{c}\text { No. of } \\
\text { ewes }\end{array}$ & Weight & $\begin{array}{c}\text { No. of } \\
\text { ewes }\end{array}$ & Weight \\
\hline $\begin{array}{l}1951 \\
1952 \\
1953 \\
1954 \\
1955\end{array}$ & $\begin{array}{l}15 \\
20 \\
20 \\
19 \\
19\end{array}$ & $\begin{array}{l}124.3 \mathrm{a}^{1} \\
111.6 \mathrm{a}^{2} \\
128.4 \mathrm{a} \\
127.8 \mathrm{a} \\
129.3 \mathrm{a}\end{array}$ & $\begin{array}{l}16 \\
20 \\
18 \\
19 \\
20\end{array}$ & $\begin{array}{l}123.8 \mathrm{a} \\
110.5 \mathrm{a} \\
125.2 \mathrm{a} \\
127.6 \mathrm{a} \\
135.4 \mathrm{a}\end{array}$ & $\begin{array}{l}17 \\
20 \\
20 \\
19 \\
20\end{array}$ & $\begin{array}{l}120.8 \mathrm{a} \\
111.6 \mathrm{a} \\
132.0 \mathrm{a} \\
135.0 \mathrm{a} \\
138.0 \mathrm{a}\end{array}$ \\
\hline $\begin{array}{l}1956 \\
1957 \\
1958 \\
1959 \\
1960\end{array}$ & $\begin{array}{l}20 \\
20 \\
18 \\
20 \\
20\end{array}$ & $\begin{array}{l}111.8 \mathrm{a} \\
112.0 \mathrm{a} \\
112.0 \mathrm{a} \\
122.7 \mathrm{a} \\
131.8 \mathrm{a}\end{array}$ & $\begin{array}{l}18 \\
19 \\
19 \\
18 \\
20\end{array}$ & $\begin{array}{l}108.9 \mathrm{a} \\
111.9 \mathrm{a} \\
123.8 \mathrm{~b} \\
127.3 \mathrm{~b} \\
139.7 \mathrm{~b}\end{array}$ & $\begin{array}{l}19 \\
20 \\
20 \\
20 \\
19\end{array}$ & $\begin{array}{l}115.2 \mathrm{a} \\
120.6 \mathrm{a} \\
123.6 \mathrm{~b} \\
135.8 \mathrm{c} \\
148.8 \mathrm{c}\end{array}$ \\
\hline $\begin{array}{l}1961 \\
1962 \\
1963 \\
1964 \\
1965\end{array}$ & $\begin{array}{l}19 \\
18 \\
16 \\
20 \\
17\end{array}$ & $\begin{array}{l}139.1 \mathrm{a} \\
128.3 \mathrm{a} \\
139.7 \mathrm{a} \\
130.1 \mathrm{a} \\
129.6 \mathrm{a}\end{array}$ & $\begin{array}{l}20 \\
19 \\
19 \\
20 \\
17\end{array}$ & $\begin{array}{l}143.6 \mathrm{a} \\
135.9 \mathrm{~b} \\
144.5 \mathrm{a} \\
136.6 \mathrm{~b} \\
143.6 \mathrm{~b}\end{array}$ & $\begin{array}{l}20 \\
19 \\
18 \\
19 \\
17\end{array}$ & $\begin{array}{l}147.7 \mathrm{a} \\
141.8 \mathrm{c} \\
148.2 \mathrm{a} \\
142.9 \mathrm{c} \\
144.3 \mathrm{~b}\end{array}$ \\
\hline $\begin{array}{l}1966 \\
1967 \\
1968 \\
1969\end{array}$ & $\begin{array}{l}20 \\
19 \\
21 \\
20\end{array}$ & $\begin{array}{l}120.4 \mathrm{a} \\
125.9 \mathrm{a} \\
143.7 \mathrm{a} \\
137.7 \mathrm{a}\end{array}$ & $\begin{array}{l}21 \\
20 \\
21 \\
21\end{array}$ & $\begin{array}{l}126.4 \mathrm{~b} \\
137.9 \mathrm{~b} \\
148.4 \mathrm{a} \\
145.7 \mathrm{~b}\end{array}$ & $\begin{array}{l}20 \\
18 \\
19 \\
20\end{array}$ & $\begin{array}{l}131.8 \mathrm{c} \\
141.3 \mathrm{~b} \\
151.9 \mathrm{a} \\
155.8 \mathrm{c}\end{array}$ \\
\hline Total or mean & 361 & $126.6 \mathrm{a}$ & 365 & $131.4 \mathrm{~b}$ & 364 & $136.2 \mathrm{c}$ \\
\hline
\end{tabular}

${ }^{1}$ Within each year, means followed by the same letter do not differ significantly at the $5 \%$ level.

During the first 7 years there were no differences in lambing weight of ewes on the various grazing intensities (Table 4). In 9 of the remaining 12 years ewes grazed at the heavy rate were lighter than those grazed at the moderate or light rates at lambing time.

\section{Discussion and Conclusions}

Continuous heavy grazing by sheep changed the vegetative cover of StipaBouteloua prairie. The large increase in basal area of blue grama, the decrease of western wheatgrass, and the scarcity of needleandthread on the heavily grazed field are characteristic changes in range deterioration. Similar changes in vegetation subjected to heavy grazing by sheep have been shown by Woolfolk (1949), Lang et al. (1956), and Rauzi et al. (1967). Under light grazing, the decrease in cover of blue grama and the increase in needleandthread is an indication of range improvement.

The changes in the vegetative cover were reflected in forage production. Under the heavy rate of grazing, the decrease in productivity of forage was due to the increase in amount of blue grama, the decrease in amount of western wheatgrass, and the reduced vigor of the plant cover. Increases in basal area of blue grama have been shown to affect the production of underground plant material and some of the soil properties in the Ah horizon (Smoliak et al., 1972). The blue grama plants on the heavily grazed field were observed to be more numerous and smaller than those on the lightly grazed field. Woolfolk (1949) indicated that close grazing and severe trampling associated with heavy stocking prevented small blue grama mats from merging into compact clumps.

The reduction in basal area of forbs resulted from heavy utilization of these species. Fringed sage, utilized during early summer on all fields, was restricted in growth in most years. Pricklypear was observed to have been eaten by the sheep in certain years. In general, all perennial forbs species decreased when grazed by sheep. Annual forbs of low forage value, such as woolly plantain, increased under these conditions. An increase in annual forb species, reported by Woolfolk (1949), occurred when recovery of palatable perennial forbs was retarded by heavy stocking with sheep. The findings of the present study contrast with those of Clarke et al. (1943), who reported that increases in perennial forbs occurred on ranges heavily stocked with cattle. Lodge (1954) noted an increase in abundance of broad-leaved species on grazed mixed prairie in southwestern Saskatchewan.

Production of forage on the three fields was closely related to body weight of ewes. Continuous heavy grazing reduced forage production and ewe body weights, especially during the last 12 years of the study. The lower feed sup- plies present on the heavily grazed fields were shown to affect wool production and body weight of ewes at shearing (Smoliak and Slen, 1972). The reduced forage supplies also affected birth and weaning weights of lambs. However, body weights of lambs (Fig. 1) during April 1 to August 31 and total pounds of lamb weaned were not influenced by grazing intensity.

The present study indicates that StipaBouteloua mixed prairie should be stocked at not less than 1.0 acre per mature ewe per month. Heavier stocking rates depressed forage production and resulted in a deteriorated vegetative cover and in lower body weights of ewes and weaning weights of lambs. Stocking at 1.0 acre per mature ewe per month maintained the vegetative cover in a productive condition.

\section{Literature Cited}

Clarke, S. E., J. A. Campbell, and J. B. Campbell. 1942. An ecological and grazing capacity study of the native grass pastures in southern Alberta, Saskatchewan, and Manitoba. Can. Dep. Agr. Tech. Bull. 44. 31 p.

Clarke, S. E., E. W. Tisdale, and N. A. Skoglund. 1943. The effects of climate and grazing practices on short grass prairie vegetation in southern Alberta and southwestern Saskatchewan. Can. Dep. Agr. Tech. Bull. $46.53 \mathrm{p}$.

Lang, R. L., O. K. Barnes, and F. Rauzi. 1956. Shortgrass range-Grazing effects on vegetation and on sheep gains. Wyo. Agr. Exp. Sta. Bull. $343.32 \mathrm{p}$.

Lodge, R. W. 1954. Effects of grazing on the soils and forage of mixed prairie in southwestern Saskatchewan. J. Range Manage. 7:166-170

MacNaughton, W. N. 1956. Repeatability and heritability of birth, weaning and shearling weights among sheep in Canada. Ph.D. thesis. Iowa State College, Ames, Iowa.

Peters, H. F. 1958. Progress report, 1954-1958. Experimental Farm, Manyberries, Alberta. Can. Dep. Agr. Publ. 27 p.

Rauzi, F., and R. L. Lang. 1967. Effect of grazing intensity on vegetation and sheep gains on shortgrass rangeland. Wyo. Agr. Exp. Sta. Sci. Monograph 4. 11 p.

Smoliak, S. 1965. A comparison of ungrazed and lightly grazed Stipa-Bouteloua prairie in southeastern Alberta. Can. J. Plant Sci. 45:270-275.

Smoliak, S., J. F. Dormaar, and A. Johnston. 1972. Long-term grazing effects on StipaBouteloua prairie soils. J. Range Manage. 25:246-250.

Smoliak, S., and S. B. Slen. 1972. Wool production of range ewes at three intensities of grazing. Can. J. Anim. Sci. 52:485-490.

Thetford, F. O., R. D. Pieper, and A. B. Nelson. 1971. Botanical and chemical composition of cattle and sheep diets on pinyon-juniper grassland range. J. Range Manage. $24: 425-431$.

Woolfolk, E. J. 1949. Stocking northern Great Plains sheep range for sustained high production. U. S. Dep. Agr. Circ. 804. 39 p. 